\title{
Selection of diazotrophic bacteria isolated from wastewater treatment plant sludge at a poultry slaughterhouse for their effect on maize plants ${ }^{1}$
}

\author{
Jorge Avelino Rodriguez Lozada², Klever Cristiano Silveira² , Libério Junio da Silva², Marihus Altoé Baldotto², \\ Lílian Estrela Borges Baldotto ${ }^{2 *}$
}

10.1590/0034-737X201865010011

\begin{abstract}
The economic and environmental costs of nitrogen fertilization have intensified the search for technologies that reduce mineral fertilization, for example atmospheric nitrogen-fixing (diazotrophic) bacteria inoculation. In this context, the present study addressed the isolation and quantification of diazotrophic bacteria in the sludge from treated wastewater of a poultry slaughterhouse; a description of the bacteria, based on cell and colony morphology; and an assessment of growth and $\mathrm{N}$ content of maize plants in response to inoculation. Sixteen morphotypes of bacteria were isolated in six Nfree culture media (JMV, JMVL, NFb, JNFb, LGI, and LGI-P). The bacteria stained gram-positive, with 10 rod- and six coccoid-shaped isolates. To evaluate the potential of bacteria to promote plant growth, maize seeds were inoculated. The experiment consisted of 17 treatments (control plus 16 bacterial isolates) and was carried out in a completely randomized design with six replicates. The experimental units consisted of one pot containing two maize plants in a greenhouse. Forty-five days after planting, the variables plant height, leaf number, stem diameter, root and shoot fresh and dry weight, and $\mathrm{N}$ content were measured. The highest values were obtained with isolate UFV L-162, which produced $0.68 \mathrm{~g}$ total dry matter per plant and increased $\mathrm{N}$ content to $22.14 \mathrm{mg} / \mathrm{plant}$, representing increments of 74 and $133 \%$, respectively, compared with the control. Diazotrophs inhabit sludge from treated wastewater of poultry slaughterhouses and can potentially be used to stimulate plant development and enrich inoculants.
\end{abstract}

Key words: Zea mays L.; plant growth-promoting bacteria; nitrogen; solid waste.

\section{RESUMO}

\section{Seleção de bactérias diazotróficas isoladas de estação de tratamento de efluentes de abatedouro de aves e seu efeito em plantas de milho}

Os custos econômico-ambientais gerados pela fertilização nitrogenada têm incrementado o interesse em tecnologias que diminuam a aplicação de fertilizantes minerais, como por exemplo, a inoculação de bactérias fixadoras de nitrogênio atmosférico, também denominadas diazotróficas. Nesse contexto, o presente trabalho objetivou: (i) isolar e quantificar bactérias diazotróficas do lodo gerado em estação de tratamento de efluentes de abatedouro de aves; (ii) caracterizar as bactérias de acordo com a morfologia celular e morfologia da colônia e (iii) avaliar o crescimento e conteúdo de $\mathrm{N}$ em plantas de milho em resposta à inoculação. Foram isolados 16 morfotipos de bactérias nos seis meios de cultivo sem adição de nitrogênio JMV, JMVL, NFb, JNFb, LGI e LGI-P. As bactérias apresentaram coloração gram positiva, sendo dez isolados com formato de bastonete e seis com formato de cocos. Para avaliar o potencial de promoção do crescimento de plantas realizou-se a inoculação em sementes de milho. O experimento, conduzido em casa-de-vegetação, consistiu de 17 tratamentos (controle e 16 isolados bacterianos), em delineamento inteiramente casualizado, com seis repetições

\footnotetext{
Submitted on March 20 th, 2017 and accepted on February 16 th, 2018.

${ }^{1}$ This work is part of the master's degree thesis of the first author.

${ }^{2}$ Universidade Federal de Viçosa, Campus Florestal, Rodovia LMG 818, km 06, 35690-000, Florestal, Minas Gerais, Brasil. jarodriguezlo28@gmail.com; klevercris@gmail.com; liberiojunior@gmail.com; marihus@ufv.br; lilian.estrela@ufv.br

*Corresponding author: lilian.estrela@ufv.br
} 
e a unidade experimental foi um vaso contendo duas plantas de milho. Aos 45 dias após o plantio, foram mensuradas as variáveis: altura da planta, número de folhas, diâmetro do caule, matéria fresca e seca da raiz e parte aérea e conteúdo de N. Os maiores valores foram obtidos com o isolado UFV L-162, proporcionando matéria seca total de $0,68 \mathrm{~g} /$ planta e um conteúdo de $\mathrm{N}$ de $22,14 \mathrm{mg} /$ planta, representando incrementos em relação ao controle de $74 \%$ e $133 \%$, respectivamente. Conclui-se que bactérias diazotróficas habitam o lodo das estações de tratamento de efluentes de abatedouro de aves e possuem potencial para uso como estimulantes do desenvolvimento vegetal e enriquecimento de inoculantes.

Palavras-chave: Zea mays L.; bactérias promotoras do crescimento de plantas; nitrogênio; resíduos sólidos.

\section{INTRODUCTION}

The high economic and environmental costs resulting from nitrogen fertilization have stimulated research for strategies to reduce mineral fertilization without compromising crop yields (Guimarães, 2011). Besides plant breeding with a view to developing cultivars more adaptable to low fertility soils and unfavorable agroenvironmental conditions, biotechnological studies with plant growth-promoting bacteria (PGPB) have also focused on the biodiversity and bioprospection of new microorganisms (Mitter et al., 2013).

Plant growth-promoting bacteria stimulate plant growth by direct mechanisms, e.g., nitrogen fixation, phosphate solubilization, and synthesis of growth regulators, and by indirect mechanisms such as the production of siderophores and allelochemicals, biological control, and induction of local and systemic resistance (Hallmann et al., 1997).

Biological nitrogen fixation (BNF) is one of the actions of PGPB and is performed by means of bacteria known as diazotrophs, which are free-living or associated with plant tissues (Hallmann et al., 1997; Baldotto et al., 2011). The process of $\mathrm{BNF}$ is essential to transform $\mathrm{N}_{2}$, a stable and abundant molecule in the atmosphere that cannot be directly used by plants, into the inorganic form $\mathrm{NH}_{3}$ and, subsequently, into organic and inorganic forms which can be used in biological systems. The reduction reactions from $\mathrm{N}_{2}$ to $\mathrm{NH}_{3}$ are mediated by microorganisms containing the enzyme nitrogenase (Kim \& Rees, 1994).

Knowledge about the relationship between nitrogenfixing bacteria and maize plants is extremely interesting, since maize is one of the three most important crops in Brazil and around the world. In addition to its economic aspect, this crop is vitally important in social and political contexts (Oliveira et al., 2007). Interactions between PGPB and the maize environment have been demonstrated in several studies and by various authors (Kappes et al., 2013; Baptista et al., 2011; Ikeda et al. 2010), with promising results in the search for economic and sustainable fertilization systems.
Nitrogen-fixing bacteria have been isolated from different sources, for example, from plant organs (Grayston et al., 1998), soils (Nóbrega et al., 2004), and organic residues (Aguiar, 2012). The sludge generated in wastewater treatment plants of poultry slaughterhouses has high microbial diversity (Bettiol \& Fernandes, 2004) and can also harbor diazotrophs. This sludge is defined as a mixture of substances that generally contains high amounts of mineral colloids and particles from decomposed organic matter suspended in the aqueous medium (CONAMA, 2006).

Given the above, this study addressed the isolation of diazotrophic bacteria from sludge of treated wastewater from a poultry slaughterhouse and quantification in different culture media; the characterization of the bacteria, based on cell and colony morphology; and the selection of bacterial isolates promoting maize growth in a greenhouse.

\section{MATERIAL AND METHODS}

\section{Collection and characterization of sludge samples}

Samples of poultry slaughterhouse sludge, a waste (composted of blood, viscera, tissues, feathers, and bones) generated in the effluents from treatment plants of the activated sludge/extended aeration type, were provided by the company Francap SA (Francap, 2015). Samples were collected from the sludge generated at the end of the treatment process and transported to the Campus Florestal of the Universidade Federal de Viçosa (UFV), where microbiological analysis were carried out in 2013 and 2014. The chemical properties of the sludge were determined as: $\mathrm{N}=9.55, \mathrm{P}=1.21, \mathrm{~K}=0.45, \mathrm{Ca}=1.35, \mathrm{Mg}=0.18, \mathrm{~S}=0.77$, and $\mathrm{CO}=18.72 \mathrm{dag} / \mathrm{kg} ; \mathrm{Zn}=517, \mathrm{Fe}=1908, \mathrm{Mn}=114, \mathrm{Cu}$ $=342$, and $\mathrm{B}=8.3 \mathrm{mg} / \mathrm{kg} ; \mathrm{pH}=6.7$; and $\mathrm{C} / \mathrm{N}=1.96$.

\section{Isolation and quantification of diazotrophs}

The diazotrophic bacteria were isolated as described by Döbereiner et al. (1995). Samples of $10 \mathrm{~g}$ sludge were diluted in $90 \mathrm{~mL}$ saline solution $\left(0.85 \mathrm{~g} \mathrm{~L}^{-1} \mathrm{NaCl}\right)$ and from this dilution $\left(10^{-1}\right)$, serial dilutions were performed to $10^{-6}$ 
dilution. Aliquots of $100 \mu \mathrm{L}$ of the different dilutions were transferred in triplicate to glass bottles containing $5 \mathrm{~mL}$ of semi-solid N-free culture media JNFb, NFB, LGI, LGI-P, JMV, and JMVL. The formation of a typical aerotaxic film on the surface of the medium incubated for seven days in a growth chamber at $30{ }^{\circ} \mathrm{C}$ was considered a positive result. The bacteria in the culture medium were counted by the most probable number (MPN) technique, using the McCrady table for three replicates per dilution. The results were logtransformed, and the mean and standard error of the mean were calculated for each treatment.

\section{Cell characterization and bacterial colonies}

After isolation, the bacteria were grown in liquid DYGS medium for $24 \mathrm{~h}$ at $30{ }^{\circ} \mathrm{C}$ with agitation at $120 \mathrm{rpm}$ and placed on Petri plates containing solid DYGS medium (Döbereiner et al., 1995). The trays were maintained in a bacteriological incubator at $30{ }^{\circ} \mathrm{C}$ for seven days. The resulting colonies were characterized based on the cell characteristics (shape and gram staining) and the characteristics of the colonies (shape, color, size, elevation, edge, surface, and mucus) (Perin, 2003; Lozada et al., 2017). Each bacterial isolate was named by the following scheme: UFV L-ABC, in which UFV = Federal University of Viçosa; $\mathrm{L}=$ sludge; $\mathrm{A}=$ isolation culture medium $(1=\mathrm{JMV}, 2=$ JMVL, 3 = NFb, 4 = JNFb, 5 = LGI, 6 = LGI-P); $\mathrm{B}=$ dilution; and $\mathrm{C}=$ number of the isolate in the collection.

\section{Selection for nitrogen-fixing, maize growth- promoting bacteria}

The bacterial selection experiment consisted of 17 treatments, 16 bacterial isolates, and one control (no inoculation), performed in a greenhouse in a completely randomized design with six replicates, based on experimental units of one pot containing two maize plants.

To obtain the pre-inoculum, bacteria were grown in 5$\mathrm{mL}$ liquid DYGS medium for $24 \mathrm{~h}$ at $30{ }^{\circ} \mathrm{C}$ and $120 \mathrm{rpm}$. Then, the pre-inoculum was poured into Erlenmeyer flasks containing $200 \mathrm{~mL}$ liquid DYGS medium. The flasks were shaken for $24 \mathrm{~h}$ at $120 \mathrm{rpm}$ at $30{ }^{\circ} \mathrm{C}$ to obtain the inoculum. Inoculation consisted of immersion of maize seeds ( $\mathrm{Zea}$ mays L. variety AG1051) for $2 \mathrm{~h}$ in the flask, followed by application of the bacterial medium to the substrate. The control was immersed in autoclaved liquid DYGS. Subsequently, the seeds were transferred to $0.7-\mathrm{dm}^{3}$ plastic pots containing soil. The soil used was collected near the UFV-CAF dryer (geographic coordinates: 1987'53.91' S and $44^{\circ} 42^{\prime} 26.55^{\prime \prime} \mathrm{W}$ ), which is classified as subsurface horizon of Dystrophic Red Latosol (Embrapa, 2013), whose chemical analysis presented: $\mathrm{pH}: 4.1$; $\mathrm{P}: 6.8$ and $\mathrm{K}: 78 \mathrm{mg} /$ $\mathrm{dm}^{3}$; Ca: 0.6, Mg: 0.3, Al: 1.4, H+Al: 7.59, SB: 1.10, CEC : $^{\mathrm{t}}$ : 2.50 , and $\mathrm{CEC}_{(\mathrm{T})}: 8.69 \mathrm{cmol}_{\mathrm{c}} / \mathrm{dm}^{3} ; \mathrm{V}: 13$; and $\mathrm{m}: 56 \%$. Liming and fertilization were not carried out to perform the selection of diazotrophic bacteria in dystrophic environment. The pots were kept in greenhouse, monitored daily throughout the experiment, and the irrigations aimed at maintaining the field capacity between 80 and $100 \%$. The other variables, such as weed control, phytosanitary treatments, and luminosity, were controlled and maintained equal and constant for all treatments.

Forty-five days after planting, the plants were harvested for the measurement of the variables: plant height $(\mathrm{PH})$, stem diameter (SD), number of leaves (NL), root fresh weight (RFM), shoot fresh weight (SFM), total fresh weight (TFM), root dry matter (RDM), shoot dry matter (SDM), and total dry matter (TDM), determined by oven-drying by forced-air ventilation at $65{ }^{\circ} \mathrm{C}$ for $72 \mathrm{~h}$, followed by weighing on a precision scale.

Nitrogen concentrations were determined by the Kjeldahl method in the Soil Analysis Laboratory Viçosa Ltd., in three replicates per treatment (replicates with highest TDM) after sulfuric acid digestion of leaves and roots. The $\mathrm{N}$ contents were estimated by multiplying the TDM content by the $\mathrm{N}$ concentration.

\section{Statistical analysis}

The data were subjected to analysis of variance using program $\mathrm{R}$, and means were compared by the Tukey test at $5 \%$ probability.

\section{RESULTS AND DISCUSSION}

\section{Isolation and quantification of diazotrophs}

The bacterial isolation using different $\mathrm{N}$-free culture media resulted in the isolation of 16 diazotrophic strains from sludge of treated wastewater from poultry slaughterhouses (Table 1).

In a comparison of the number of isolates of diazotrophs from poultry slaughterhouse sludge $(n=16)$ with the results of Bergamaschi et al. (2007), consisting of 76 strains detected in sorghum plants, or with that of Ikeda et al. (2010), who isolated 217 endophytic bacteria from maize plants, the number was lower in the present study. This may be explained by effect of symbiosis among plant, bacteria, and soil (Grayston et al., 1998). Other studies corroborated this hypothesis, since in biogeographic studies of bacteria cultured from plants such as maize (Roesch et al., 2005; Gomes et al., 2010), rice (Ferreira et al., 2003), and sugarcane (Perin, 2003), a higher number of $\mathrm{N}$-fixing bacteria was found in roots than in shoots, or in environments involving interaction with soil.

The highest amount of diazotrophs was observed in the JMV medium (log MPN/g sludge $=7.15)$ and lowest in the JMVL medium $(\log$ MPN/g sludge $=6.46)($ see Table 1$)$. These results are similar to the findings of Milani et al. (2011) in sugarcane. These authors isolated bacteria from soil, roots, and leaves, in amounts ranging from 5.46 to 
$7.28 \mathrm{log}$ MPN/g plant. In grasses and sugarcane, respectively, Reis et al. (2000) and Perin (2003) obtained similar results regarding the number of bacteria in poultry slaughterhouse sludge. The large number of these bacteria in the sludge can be explained by the type of treatment of the activated sludge, in which a continuous injection of air allows the proliferation of aerobic microorganisms (Sobrinho, 1983), e.g., $\mathrm{N}$-fixing bacteria.

A current fact in research for prospective diazotrophs is the variability of results in relation to the richness and abundance of species. Low richness and high abundance were found in the poultry slaughterhouse sludge. In other cases, for example, in an investigation of tropical fruits (Santos, 2008), both species richness and abundance were high and season-related.

In the study by Melloni et al. (2004), 36 diazotrophic bacterial strains were isolated from soil recovered after mining. The authors found a wide variation in the $\log$ MPN per $g$ of soil, ranging from 0 to 12 . The authors attributed the low values to the low content of organic matter in the soil, as well as to the low levels of $\mathrm{K}$ and $\mathrm{P}$ and low base saturation. This result is contrary to our findings, since the microbial abundance in sludge from poultry slaughterhouses was high, which can be attributed in part, to the high organic matter content. In this sludge, microorganisms find nutritional conditions favorable for growth. Our results indicate that diazotrophs naturally inhabit sludge from wastewater treatment plants of poultry slaughterhouses in a number exceeding $4.6 \times 10^{7}$ cells per gram of sludge.

\section{Cell characterization and bacterial colonies}

Of the 16 samples analyzed (Table 2), the colony diameter of $50 \%$ of the bacterial isolates was equal to or greater than $1 \mathrm{~mm}$. In terms of color, hues varied from milkywhite to milky yellow. The other morphological characteristics of the colonies were as follows: $100 \%$ had a round shape and smooth surface; $75 \%$ entire and 25\% undulated edges; and for the top, the colonies were 50, 30, and $20 \%$ for lense, flat, and convex, respectively.

The cell characterization (Table 3 ) showed that from all isolates stained gram-positive, $62.5 \%$ were rod-shaped and
$37.5 \%$ coccoid-shaped. This was similar to the results of Faria et al. (2009), in which 77 and $61 \%$ of strains isolated from sewage sludge from two treatment plants were grampositive. In contrast, Nóbrega et al. (2004) found that the 72 diazotrophic isolates from bacterial soil recovered after mining were gram-negative bacteria and with higher phenotypic variability. In summary, diazotrophic grampositive bacteria with a rod shape predominate in the sludge generated in the wastewater treatment plants of poultry slaughterhouses, forming colonies with different morphological characteristics.

\section{Test for selection of nitrogen-fixing bacteria in maize plants}

Diazotrophic inoculation in Zea mays plants had a positive effect on the variables RFM, TFM, and N content compared with the control (Table 4). For the variables PH, $\mathrm{SD}, \mathrm{NL}, \mathrm{SFM}, \mathrm{SDM}, \mathrm{RDM}$, and TDM, there was no difference between control and inoculation treatments (Table 4).

Similar results for plant height were verified by Lana $e t$ al. (2012), evaluating the responses of maize to Azospirillum inoculation associated with nitrogen fertilization. Dartora et al. (2013) also verified that maize plant height was not influenced by the inoculation with $A$. brasilense and $H$. seropedicae; however, contrary to the result shown here, the author noticed a positive effect of diazotrophic inoculation on the basal diameter of the stem.

Among 16 diazotrophic isolates evaluated, only three (UFVL-162, UFVL-163, and UFVL-164) differed from control in some variable (Table 4). The absence of response of maize plant to the inoculation of 13 isolates may be related to several factors such as the vulnerability of these microorganisms to the environment (Moreira et al., 2010) and absence of interaction with the host plant genotype (Roesch et al., 2005).

The bacterial isolate UFVL-163 induced the highest accumulation of TFM, with an increase of $27 \%$ over the control. These data confirmed the results of Perin et al. (2003), in which the bacterial species Herbaspirillum seropedicae and Azospirillum brasilense increased TFM of maize plants by 2 to $28 \%$. Maize is frequently used for silage production,

Table 1: Number of diazotrophic bacterial isolates per culture medium with the respective dilution and MPN (average of three replications followed by the mean standard error)

\begin{tabular}{lccc}
\hline Culture medium & Number of isolates & Dilution & log MPN/g of sludge \\
\hline JMV & 4 & $10^{-6}$ & $7.15 \pm 0.00$ \\
JMVL & 2 & $10^{-6}$ & $6.46 \pm 0.29$ \\
NFB & 4 & $10^{-6}$ & $6.95 \pm 0.15$ \\
JNFB & 3 & $10^{-5}$ & $6.48 \pm 0.09$ \\
LGI & 1 & $10^{-6}$ & $7.11 \pm 0.03$ \\
LGI-P & 2 & $10^{-6}$ & $7.04 \pm 0.00$ \\
\hline
\end{tabular}

MPN - most probable number.

Rev. Ceres, Viçosa, v. 65, n.1, p. 085-092, jan/fev, 2018 
as it has better qualities for feed than other species. The use of PGPB in maize destined for silage can be a viable alternative means of producing feed for animal species raised in confined and semi-confined systems or for periods with low forage production (Matte, 2014).

Inoculation with isolate UFV-164 increased RDM by $91 \%$ compared with that of the control. This result was better than the cumulative root biomass increase of 3 to $17 \%$ reported by Perin et al. (2003) in studies with Zea mays L. after inoculation with diazotrophs (H. seropedica and $A$. brasilense). By increasing root biomass production, the plants can become more efficient in absorbing nutrients and water from the soil. Consequently, this is reflected in greater shoot biomass, better plant health, and higher yield.

The highest $\mathrm{N}$ contents in maize plants were induced by inoculation with isolate UFVL-162, corresponding to an increase of $134 \%$ over the control. An increase of $41 \%$ in maize $\mathrm{N}$ content was observed by Obando et al. (2013) after inoculation with Azotobacter. Similarly, Reyes et al. (2008) observed an $88 \%$ increase in $\mathrm{N}$ content in maize plants inoculated with rhizobacteria.

The present work aimed to select the diazotrophic bacteria in a dystrophic environment, the same strategy used by Inagaki (2014) when evaluating the influence of soil pH on the colonization of maize plants by A. brasilense and $H$. seropedicae. The author concluded that acid $\mathrm{pH}$ $(4.5,5.0$, and 5.5) had no influence on the population of these two diazotrophic bacteria in maize plants evaluated at 41 days after sowing. However, Baldotto et al. (2012) observed that the population of diazotrophic bacteria in maize plants evaluated at 30 days after sowing can be favored with the application of 25 to $75 \%$ of NPK recommended dose.
This study demonstrated the colonization capacity of diazotrophic bacteria isolated from environments of residues such as treated sludge from a poultry slaughterhouse. This sludge can be applied to environmental restoration processes and as raw material for manufacturing substrates and biofertilizer (Santos et al., 2014), and can be exploited as a source of microbial diversity for studies of bacteria with potential for degrading organic substances (Lozada et al., 2017) and plant growthpromoting bacteria. In conclusion, bacterial isolates from sludge of poultry slaughterhouses, in particular UFVL162, UFVL-163, and UFVL-164, promote the growth and development of maize plants.

Table 3: Cell characterization of bacterial isolates from treated sludge of poultry slaughterhouse wastewater

\begin{tabular}{lcc}
\hline Isolate & Shape & Gram staining \\
\hline UFV L-161 & Rod & + \\
UFV L-162 & Rod & + \\
UFV L-163 & Rod & + \\
UFV L-164 & Rod & + \\
UFV L-261 & Coccoid & + \\
UFV L-262 & Coccoid & + \\
UFV L-361 & Coccoid & + \\
UFV L-362 & Coccoid & + \\
UFV L-363 & Coccoid & + \\
UFV L-364 & Rod & + \\
UFV L-451 & Rod & + \\
UFV L-452 & Rod & + \\
UFV L-453 & Rod & + \\
UFV L-562 & Coccoid & + \\
UFV L-661 & Rod & + \\
UFV L-662 & Rod & + \\
\hline
\end{tabular}

Table 2: Characterization of colonies of bacterial isolates from treated sludge of poultry slaughterhouse wastewater in specific media

\begin{tabular}{lccccccc}
\hline Isolate & Color & Size & Top & Shape & Edge & Surface & Mucu \\
\hline UFV L-161 & Milk-white center & $<1 \mathrm{~mm}$ & Lense & Round & Straight & Smooth & + \\
UFV L-162 & Clear white center, white and translucent edge & $<1 \mathrm{~mm}$ & Flat & Round & Undulated & Smooth & + \\
UFV L-163 & Milk-white center, white and translucent edge & $1 \mathrm{~mm}$ & Lense & Round & Straight & Smooth & + \\
UFV L-164 & White center, white and translucent edge & $1 \mathrm{~mm}$ & Flat & Round & Straight & Smooth & + \\
UFV L-261 & Milk-white center & $1 \mathrm{~mm}$ & Lense & Round & Undulated & Smooth & + \\
UFV L-262 & Milky yellow center & $>1 \mathrm{~mm}$ & Convex & Round & Undulated & Smooth & + \\
UFV L-361 & Milk-white center & $<1 \mathrm{~mm}$ & Lense & Round & Straight & Smooth & + \\
UFV L-362 & Milk-white center & $>1 \mathrm{~mm}$ & Convex & Round & Straight & Smooth & + \\
UFV L-363 & White center & $1 \mathrm{~mm}$ & Flat & Round & Straight & Smooth & + \\
UFV L-364 & Clear white center, translucent edge & $>1 \mathrm{~mm}$ & Lense & Round & Straight & Smooth & + \\
UFV L-451 & Milk-white center, translucent edge & $<1 \mathrm{~mm}$ & Flat & Round & Undulated & Smooth & + \\
UFV L-452 & White center. translucent edge & $<1 \mathrm{~mm}$ & Lense & Round & Straight & Smooth & + \\
UFV L-453 & Milk-white center, white and translucent edge & $>1 \mathrm{~mm}$ & Convex & Round & Straight & Smooth & + \\
UFV L-562 & Clear white center, translucent edge & $<1 \mathrm{~mm}$ & Flat & Round & Straight & Smooth & - \\
UFV L-661 & Clear white center, clear edge & $<1 \mathrm{~mm}$ & Flat & Round & Straight & Smooth & - \\
UFV L-662 & Clear white center, clear edge & $<1 \mathrm{~mm}$ & Convex & Round & Straight & Smooth & - \\
\hline
\end{tabular}

Identification of bacterial strains: UFV name followed by the characters that indicate sludge $(\mathrm{L})$, isolation culture medium $(1=\mathrm{JMV}, 2=$ JMVL, $3=\mathrm{NFb}, 4$ = JNFb, 5 = LGI, 6 = LGI-P), dilution, order. 


\begin{tabular}{|c|c|c|c|c|c|}
\hline $\begin{array}{c}\text { SFM } \\
\mathbf{g} \\
\end{array}$ & $\begin{array}{c}\text { TFM } \\
\mathrm{g} \\
\end{array}$ & $\begin{array}{c}\text { SDM } \\
\mathrm{g} \\
\end{array}$ & $\begin{array}{c}\text { RDM } \\
\mathbf{g} \\
\end{array}$ & $\begin{array}{c}\text { TDM } \\
\mathbf{g} \\
\end{array}$ & $\begin{array}{l}\text { N CONT } \\
\text { mg/plant }\end{array}$ \\
\hline $4.00 \mathrm{ab}$ & $5.62 \mathrm{bc}$ & $0.10 \mathrm{a}$ & $0.28 \mathrm{abc}$ & $0.39 \mathrm{ab}$ & $9.48 \mathrm{~b}$ \\
\hline $4.13 \mathrm{ab}$ & $6.42 \mathrm{abc}$ & $0.14 \mathrm{a}$ & $0.45 \mathrm{ab}$ & $0.60 \mathrm{ab}$ & $14.68 \mathrm{ab}$ \\
\hline $4.74 \mathrm{a}$ & $6.92 \mathrm{abc}$ & $0.16 \mathrm{a}$ & $0.51 \mathrm{a}$ & $0.68 \mathrm{a}$ & $22.14 \mathrm{a}$ \\
\hline $4.13 \mathrm{ab}$ & $7.17 \mathrm{a}$ & $0.20 \mathrm{a}$ & $0.28 \mathrm{abc}$ & $0.49 \mathrm{ab}$ & $15.17 \mathrm{ab}$ \\
\hline $3.95 \mathrm{ab}$ & $7.05 \mathrm{ab}$ & $0.23 \mathrm{a}$ & $0.31 \mathrm{abc}$ & $0.55 \mathrm{ab}$ & $13.50 \mathrm{ab}$ \\
\hline $3.31 \mathrm{ab}$ & $5.51 \mathrm{abc}$ & $0.16 \mathrm{a}$ & $0.24 \mathrm{bc}$ & $0.41 \mathrm{ab}$ & $11.28 \mathrm{ab}$ \\
\hline $3.00 \mathrm{ab}$ & $5.08 \mathrm{abc}$ & $0.17 \mathrm{a}$ & $0.20 \mathrm{bc}$ & $0.38 \mathrm{ab}$ & $10.17 \mathrm{~b}$ \\
\hline $3.62 \mathrm{ab}$ & $5.33 \mathrm{bc}$ & $0.11 \mathrm{a}$ & $0.14 \quad \mathrm{c}$ & $0.25 \mathrm{~b}$ & $8.07 \mathrm{~b}$ \\
\hline $3.10 \mathrm{ab}$ & $4.8 \mathrm{c}$ & $0.10 \mathrm{a}$ & $0.25 \mathrm{abc}$ & $0.36 \mathrm{ab}$ & $7.96 \mathrm{~b}$ \\
\hline $4.62 \mathrm{a}$ & $6.57 \mathrm{abc}$ & $0.13 \mathrm{a}$ & $0.23 \mathrm{bc}$ & $0.36 \mathrm{ab}$ & $9.12 \mathrm{~b}$ \\
\hline $3.40 \mathrm{ab}$ & $5.33 \mathrm{bc}$ & $0.15 \mathrm{a}$ & $0.32 \mathrm{abc}$ & $0.48 \mathrm{ab}$ & $12.96 \mathrm{ab}$ \\
\hline $4.19 \mathrm{ab}$ & $6.02 \mathrm{abc}$ & $0.17 \mathrm{a}$ & $0.18 \mathrm{c}$ & $0.35 \mathrm{ab}$ & $9.57 \mathrm{~b}$ \\
\hline $4.11 \mathrm{ab}$ & $6.52 \mathrm{abc}$ & $0.17 \mathrm{a}$ & $0.29 \mathrm{abc}$ & $0.47 \mathrm{ab}$ & $10.73 \mathrm{~b}$ \\
\hline $3.75 \mathrm{ab}$ & $6.19 a b c$ & $0.16 \mathrm{a}$ & $0.26 \mathrm{abc}$ & $0.42 \mathrm{ab}$ & $11.21 \mathrm{ab}$ \\
\hline $3.10 \mathrm{ab}$ & $5.07 \mathrm{bc}$ & $0.15 \mathrm{a}$ & $0.30 \mathrm{abc}$ & $0.41 \mathrm{ab}$ & $8.280 \mathrm{~b}$ \\
\hline $4.18 \mathrm{ab}$ & $6.22 \mathrm{abc}$ & $0.15 \mathrm{a}$ & $0.18 \mathrm{c}$ & $0.34 \mathrm{ab}$ & $4.63 \mathrm{~b}$ \\
\hline $2.55 \mathrm{~b}$ & $4.474 \mathrm{c}$ & $0.16 \mathrm{a}$ & $0.34 \mathrm{abc}$ & $0.50 \mathrm{ab}$ & $11.98 \mathrm{ab}$ \\
\hline 0.935 & 1.681 & 0.015 & 0.0168 & 0.028 & 13.696 \\
\hline 1.986 & 2.662 & 0.251 & 0.2661 & 0.344 & 7.599 \\
\hline 25.6 & 21.8 & 76.9 & 45.3 & 37.4 & 32.9 \\
\hline
\end{tabular}

\section{Treatments}

PH

SD

unit

RFM

4 abcde

g

$2.45 \mathrm{ab}$

$1.62 \mathrm{~b}$

UFV L-161 14.10 ab

$2.75 \mathrm{ab}$

$6 \mathrm{ab}$

$2.29 \mathrm{ab}$

$6 \mathrm{ab} \quad 2.18 \mathrm{ab}$

UFV L-162

$17.24 \mathrm{ab}$

$3.08 \mathrm{ab}$

UFV L-163

$20.35 \mathrm{a}$

$3.33 \mathrm{ab}$

UFV L-164

$19.51 \mathrm{a}$

$3.37 \mathrm{ab}$

UFV L-262

$20.15 \mathrm{a}$

$3.04 \mathrm{ab}$

$6 \mathrm{ab}$

$3.10 \mathrm{a}$

$2.20 \mathrm{ab}$

$2.65 \mathrm{ab}$

5 abcd

2.08 b

4 bcde

$1.71 \mathrm{~b}$

$1.7 \mathrm{~b}$

$2.43 \mathrm{~b}$

UFV L-362

$13.45 \mathrm{ab}$

UFV L-363 $\quad 17.54 \mathrm{ab}$

UFV L-364 $\quad 13.95 \mathrm{ab}$

UFV L-451 $\quad 12.08$ b

UFV L-452 $\quad 18.95 \mathrm{ab}$

UFV L-453 $\quad 17.58 \mathrm{ab}$

UFV L-562 $\quad 17.62 \mathrm{ab}$

UFV L-661 $\quad 15.45 \mathrm{ab}$

UFV L-662

$15.16 \mathrm{ab}$

MSD $\quad 7.90$

CV $(\%)$

22.8

$2.93 \mathrm{ab}$

$2.68 \mathrm{ab}$

$2.50 \mathrm{ab}$

$3.04 \mathrm{ab}$

$3.18 \mathrm{ab}$

4 de

4 de

$3 \mathrm{ed}$

$1.95 \mathrm{~b}$

$1.93 \mathrm{~b}$

5 abcd

$1.93 \mathrm{~b}$

5 abcd

$2.41 \mathrm{ab}$

$1.97 \mathrm{~b}$

$2.04 \mathrm{~b}$

$6 \mathrm{abc}$

$2.19 \mathrm{ab}$

$\begin{array}{ll}17.6 & 1.48 \\ - & 15.1\end{array}$

0.98

25.6

21.8

0.251
76.9

45.3

37.4

32.9

total dry matter; N CONT - nitrogen content; RMS - residual mean square; MSD - minimum significant difference; CV - coefficient of variation.

Averages followed by the same letter do not differ by the Tukey test $(\mathrm{p}>0.05 ; \mathrm{n}=6)$. 


\section{CONCLUSIONS}

Diazotrophs naturally inhabit sludge from wastewater treatment plants of poultry slaughterhouses, are predominantly gram-positive bacteria with a rod shape, and form colonies with different morphological characteristics.

Bacterial isolates from sludge of poultry slaughterhouses, in particular UFVL-162, UFVL-163, and UFVL-164, promote the growth and development of maize plants and can potentially be used to enrich inoculants and biofertilizers or in agricultural systems with low inputs or low fertility.

\section{ACKNOWLEDGEMENTS}

The authors thank the company Francap SA and Débora Durães, a laboratory technician at the Universidade Federal de Viçosa-Campus Florestal (UFV-CAF). They also thank Fundação Arthur Bernardes (FUNARBE), for financial support, and the Coordenação de Aperfeiçoamento de Pessoal de Nível Superior (CAPES), for a scholarship granted to the first author, in the area of Management and Conservation of Natural and Agrarian Ecosystems, UFV-CAF.

\section{REFERENCES}

Aguiar KP (2012) Prospecção de bactérias promotoras do crescimento vegetal associadas a vermicompostos. Master Dissertation. Universidade Estadual do Norte Fluminense Darcy Ribeiro, Campos dos Goytacazes. 86p.

Baldotto LEB, Olivares FL \& Bressan-Smith R (2011) Structural interaction between GFP-labeled diazotrophic endophytic bacterium Herbaspirillum seropedicae RAM10 and pineapple plantlets 'Vitória'. Brazilian Journal of Microbiology, 42:114125

Baldotto MA, Baldotto LEB, Santana RB \& Marciano CR (2012) Initial performance of maize in response to NPK fertilization combined with Herbaspirillum seropedicae. Revista Ceres, 59:841-849.

Baptista RB, Mauri R \& Baldani VLD (2011) Tolerância de estirpes de bactérias diazotróficas a $\mathrm{Al}^{3+}$, para inoculação em milho (Zea mays L.). Revista de Ciência da Vida, 31:36-46.

Bettiol W \& Fernandes SAP (2004) Efeito do lodo de esgoto na comunidade microbiana e atributos químicos do solo. Jaguariúna, Embrapa Meio Ambiente. 6p. (Comunicado Técnico, 24).

Bergamaschi CBLFW, Roeschr L, de Quadros PD \& Camargo FA (2007) Ocorrência de bactérias diazotróficas associadas a cultivares de sorgo forrageiro. Ciência Rural, 37:727-733.

CONAMA (2006) Conselho Nacional do Meio Ambiente. Resolução $\mathrm{N}^{\circ}$. 375 de 29 de Agosto de 2006. Available on: <www.mma.gov.br/port/conama/res/res06/res37506.pdf >. Accessed on October $28^{\text {th }}, 2015$

Dartora J, Guimarães VF, Marini D \& Sander G (2013) Nitrogen fertilization associated to inoculation with Azospirillum brasilense and Herbaspirillum seropedicae in the maize. Revista Brasileira de Engenharia Agrícola e Ambiental, 17:10231029 .
Döbereiner J, Baldani VLD \& Baldani JI (1995) Como isolar e identificar bacteìrias diazotroìficas de plantas naPo leguminosas. Seropeìdica, Embrapa Agrobiologia. 60p.

Embrapa - Empresa Brasileira de Pesquisa Agropecuária (2013) Sistema Brasileiro de Classificação de Solos. $3^{\mathrm{a}}$ ed. Rio de Janeiro, Centro Nacional de Pesquisa em Solos. 353p.

Faria CMDR, Campos VP, de Souza RM, Moreira FMS, de Moura B, de Oliveira Ribeiro L \& Farias MV (2009) Isolamento caracterização de bactérias do lodo de esgoto com potencial antagonismo a nematoides. Ambiência, 2:247-256.

Ferreira JS, Sabino DCC, Guimarães SL, Baldani JI \& Baldani, VLD (2003) Seleção de veículos para o preparo de inoculante com bactérias diazotróficas para arroz inundado. Agronomia, 37:0612.

Francap (2015) Organizações Francap S/A. Available at: http:// www.francap.ind.br/meioambiente.php. Accessed on October $28^{\text {th }}, 2015$.

Guimarães SL, Bonfim-Silva EM, Kroth BE, Moreira JFC \& Rezende D (2011) Crescimento e desenvolvimento inicial de Brachiaria decumbens inoculada com Azospirillum spp. Enciclopédia Biosfera, 7:286-295.

Gomes L, Perin L, Pereira G \& Zilli J (2010) Bactérias diazotróficas endofíticas em cultivares de milho em área de cerrado e mata no estado de Roraima. Boa Vista, Embrapa Roraima. 35p. (Documentos 43)

Grayston SJ, Wang S, Campbell CD \& Edwards AC (1998) Selective influence of plant species on microbial diversity in the rhizosphere. Soil Biology and Biochemistry, 30:369-378.

Hallmann J, Quadt-Hallmann A \& Mahaffee WF (1997) Bacterial endophytes in agricultural crops. Canadian Journal of Microbiology, 43:895-914.

Ikeda AC, Hungria M, Steffens M, Glienke C, Kava-Cordeiro V, Bassani L \& Galli-teresawa VL (2010) Caracterização morfofisiológica e genética de bactérias endofíticas isoladas de raízes de diferentes genótipos de milho (Zea mays L.). In: Congresso Brasileiro de Genética, Guarujá. Resumos, Embrapa. p. 51 .

Inagaki AM (2014) Bactérias promotoras de crescimento de plantas na cultura do milho submetido a diferentes níveis de $\mathrm{pH}$ do solo. Dissertação de Mestrado. Universidade Estadual do Oeste do Paraná, Marechal Cândido Rondon. 79p.

Kappes C, Arf O, Arf MV, Ferreira JP, Bem EDA, Portugal JR \& Vilela RG (2013) Inoculação de sementes com bactérias diazotróficas e aplicação de nitrogênio em cobertura e foliar em milho. Semina: Ciências Agrárias, 34:527-538.

Kim J \& Rees DC (1994) Nitrogenase and biological nitrogen fixation. Biochemistry, 33:389-397.

Lana MC, Dartora J, Marini D \& Hann JEH (2012) Inoculation with Azospirillum, associated with nitrogen fertilization in maize. Revista Ceres, 59:399-405.

Lozada JAR, Silveira KC, Silva LJ, Baldotto MA \& Baldotto LEB (2017) Prospecting for sludge bacteria from a poultry slaughterhouse, with potential for degrading organic substances. Semina: Ciências Agrárias, 38:1209-1216.

Matte L (2014) Inoculante com Azospirillum brasilense combinado com níveis de nitrogênio na cultura de milho para silagem. Dissertação de Mestrado. Universidade Camilo Castelo Branco, Descalvado. 48p.

Milani KML, Machineski O \& Balota EL (2011) Ocorrência e isolamento de bactérias diazotróficas associadas à cana de açúcar. Enciclopédica Biosfera, 7:1345-1351. 
Mitter B, Brader G, Afzal M, Compant S, Naveed M, Trognitz F \& Sessitsch A (2013) Advances in elucidating beneficial interactions between plants, soil, and bactéria. Advances in Agronomy, 121:381-445.

Melloni R, Nóbrega RSA, Moreira FMS \& Siqueira JO (2004) Densidade e diversidade de bactérias diazotróficas endofíticas em solos de mineração de bauxita em reabilitação. Revista Brasileira de Ciência do Solo, 28:85-93.

Moreira FFMS, Silva K, Nóbrega RSA \& Carvalho F (2010) Bactérias diazotróficas associativas: Diversidade, ecologia e potencial de aplicações. Comunicata Scientiae, 1:174-99.

Nóbrega RSA, Moreira FMS, Siqueira JO \& Lima S (2004) Caracterização fenotípica e diversidade de bactérias diazotróficas associativas isoladas de solos em reabilitação após a mineração de bauxita. Revista Brasileira de Ciência do Solo, 28:269-279.

Obando M, Rivera D \& Bonilla R (2013) Respuesta fisiológica a la fertilización por Azotobacter chroococcum AC1 y fertilización nitrogenada de síntesis sobre el maíz (Zea mays L.) en invernadero. Biotecnologia, 17:11-22.

Oliveira MSS, Roel AR, Arruda EJ \& Marques AS (2007) Eficiência de produtos vegetais no controle da lagarta do cartucho-domilho Spodoptera frugiperda (JE Smith, 1797) (Lepidoptera:Noctuidae). Semina: Ciência e Agrotecnologia, 31:326-331.

Perin L (2003) Ecologia e diversidade de isolados de Gluconacetobacter diazotrophicus associados à cultura da canade-açúcar (Saccharum spp.). Dissertação de Mestrado. Universidade Federal Rural do Rio de Janeiro, Seropédica. 74p.
Perin L, Silva MD, Ferreira JS, Canuto EL, Medeiros AFA, Olivares FL \& Reis M (2003) Avaliação da capacidade de estabelecimento endofítico de estirpes de Azospirillum e Herbaspirillum em milho e arroz. Agronomia, 37:47-53.

Reis VM, Baldani JI, Baldani VLD \& Döbereiner J (2000) Biological dinitrogen fixation in Gramineae and Palm trees. Critical Reviews in Plant Science, 19:227-247.

Reyes I, Alvarez L, El-Ayoubi H \& Valery A (2008) Selección y evaluación de rizobacterias promotoras del crecimiento en pimentón y maíz. Bioagro, 20:37-48.

Roesch LFW, Camargo FADO, Selbach PA, Sa LSD \& Passaglia LM (2005) Identificação de cultivares de milho eficientes na absorção de nitrogênio e na associação com bactérias diazotróficas. Ciência Rural, 35:924-927.

Santos ST (2008) Biogeografia de bactérias culturáveis associadas às fruteiras tropicais. Tese de Doutorado. Universidade Estadual do Norte Fluminense Darcy Ribeiro, Campos dos Goytacaes. $92 \mathrm{p}$.

Santos FE, Kunz SH, Caldeira MV, Azevedo CH \& Rangel OJ (2014) Características químicas de substratos formulados com lodo de esgoto para produção de mudas florestais. Revista Brasileira de Engenharia Agrícola e Ambiental, 18:971-979.

Sobrinho PA (1983) Estudo dos fatores que influenciam no processo de lodos ativados - determinação de parâmetros de projeto para esgotos predominantemente domésticos. Revista DAE, 132:49-55. 